\title{
Diseminasi Model Pemberdayaan Masyarakat Desa melalui Pengelolaan Agrowisata
}

\author{
IMAM SANTOSA ${ }^{1}$, RAWUH EDY PRIYONO ${ }^{2}$ \\ 1, 2Fakultas IImu Sosial dan IImu Politik, Unsoed, JI. Prof. H. R., Bunyamin No. 708 Purwokerto 53122 \\ e-mail: 12Scokronegoro@yahoo.com; 2Rawuh E_Priyono@yahoo.co.id
}

\begin{abstract}
Diversion of agricultural land to agrotourism areas urge the villagers into a trap landless and unemployment, which in turn have an impact on sustained poverty. Therefore, this study aims to examine sosial relations in the dissemination model of empowering rural communities through local resource management of agrotourism. The research location is set intentionally in the four areas into the development of agrotourism in the central region Banyumas and Purbalingga. The research method used survey with qualitative and quantitative approach. The research's results showed there was a variety of external and internal issues that hinder the dissemination of sosial relationships communicative empowerment model. However, the villagers have attempted to solve the obstacles according to the capability of local resources. Sosial relations have a significant meaning in the process of dissemination on rural community empowerment model through agrotourism management.
\end{abstract}

Keywords: empowerment model; rural communities; agrotourism management.

\begin{abstract}
Abstrak. Pengalihan fungsi lahan pertanian menjadi kawasan agrowisata mendesak masyarakat desa masuk perangkap ketunakismaan dan ketunakaryaan, yang pada gilirannya berdampak terhadap kemiskinan berlarut. Oleh karena itu, penelitian ini bertujuan mengkaji hubungan sosial pada proses diseminasi model pemberdayaan masyarakat desa melalui pengelolaan agrowisata berbasis sumberdaya lokal. Lokasi penelitian ditetapkan secara sengaja di empat kawasan yang menjadi sentral pengembangan agrowisata di wilayah Kabupaten Banyumas dan Kabupaten Purbalingga. Metode penelitian yang digunakan ialah survai dengan pendekatan kualitatif kuantitatif. Hasil penelitian menunjukkan ada ragam permasalahan eksternal dan internal yang merintangi hubungan sosial komunikatif pada diseminasi model pemberdayaan. Meski demikian, masyarakat desa telah berupaya menyelesaikan berbagai rintangan sesuai kemampuan sumberdaya lokal. Hubungan sosial memiliki keberfungsian yang berarti dalam proses diseminasi model pemberdayaan masyarakat desa melalui pengelolaan agrowisata.
\end{abstract}

Kata kunci: model pemberdayaan; masyarakat desa; pengelolaan agrowisata.

\section{Pendahuluan}

Persoalan kemiskinan mendesak ditangani secara serius oleh berbagai pihak terkait. Pengembangan di beragam bidang seringkali tak sampai menjangkau langsung kepentingan pemberdayaan segenap lapisan masyarakat miskin khususnya di pedesaan. Realitas sosial ini juga ditemukan pada masyarakat di pedesaan yang tengah dikembangkan menjadi kawasan agrowisata. Seiring pesatnya laju gerak pengembangan kepariwisataan di daerah pedesaan ternyata baru berhasil meningkatkan pertumbuhan ekonomi minoritas masyarakat lokal. Kemanfaatannya bagi warga berstatus miskin belum optimal. Kondisi sosial ini menggambarkan fakta pengembangan kepariwisataan ternyata kurang berfungsi memberdayakan masyarakat desa, yang mengorbankan banyak hal untuk memajukan daerahnya jadi obyek kawasan agrowisata.

Lahan pertanian merupakan aset utama masyarakat desa yang mayoritas berpola nafkah pokok sebagai petani. Aset utama ini terus mengalami konversi tanpa terelakkan. Jumlah masyarakat desa di kawasan agrowisata yang mengalami persoalan penyempitan lahan (landless) makin bertambah. Sementara, akses beralih pekerjaan ke non pertanian rendah. Sebagai konsekwensi, masyarakat desa di kawasan agrowisata rawan terjebak ancaman ketunakismaan dan ketunakaryaan. Dalam rentang 
waktu tidak lama, realitas sosial tersebut menimbulkan persoalan kemiskinan berlarut. Petani juga menanggung risiko atas degradasi lingkungan.

Tidak jauh berbeda dengan permasalahan yang dihadapi masyarakat pedesaan di kawasan agrowisata manapun, ternyata masyarakat pedesaan di Kawasan Agrowisata Baturaden dan Kawasan Agrowisata Cilongok (Kabupaten Banyumas) serta Kawasan Agrowisata Karangreja dan Kawasan Agrowisata Kutasari (Kabupaten Purbalingga) tengah mengalami persoalan serupa yakni belum dapat mengakses keberadaan pengembangan pariwisata di desanya untuk mendukung upaya pemberdayaam. Berdasarkan hasil penelitian Santoso, et al., (2007) dikemukakan bahwa meski ada tekanan motif ekonomi tinggi dalam budidaya aneka buah dan sayuran untuk kebutuhan agrowisata namun masyarakat desa tetap kesulitan mengelolanya sebagai sumber nafkah pokok. Demikian hasil penelitian lain dari Santoso dan Dadan (2005) mengungkapkan kontribusi agrowisata di kawasan wisata Baturaden, Kabupaten Banyumas terhadap peningkatan pendapatan mayoritas masyarakat desa khususnya petani relatif masih rendah.

Berbagai faktor melatarbelakangi permasalahan kelambanan pemberdayaan masyarakat desa dalam pengelolaan agrowisata yang berbasis sumberdaya lokal. J alinan hubungan sosial yang kurang komunikatif dengan berbagai pihak merupakan salah satu penyebab masyarakat desa sulit ikut memanfaatkan pengembangan agrowisata di lingkungannya. Deretan permasalahan yang dipaparkan menjadi dasar pertimbangan penetapan tema penelitian yakni mengenai hubungan sosial pada diseminasi model pemberdayaan masyarakat desa melalui pengelolaan agrowisata. Tujuan penelitian ialah mengkaji permasalahan, solusi dan keberfungsian hubungan sosial pada diseminasi model pemberdayaan masyarakat desa melalui pengelolaan agrowisata berbasis sumberdaya lokal.

Metode penelitian yang digunakan ialah survai sebagai kajian lapang dengan pendekatan kualitatif kuantitatif. Lokasi penelitian ditetapkan secara sengaja di empat kawasan yang menjadi sentral pengembangan kawasan pariwisata berbasis pertanian atau agrowisata di wilayah Kabupaten Banyumas dan Kabupaten Purbalingga, Propinsi J awa Tengah. Lokasi penelitian yang dimaksud adalah pedesaan Kawasan Agrowisata di Kecamatan Baturaden dan Kawasan Agrowisata di Kecamatan Cilongok mewakili wilayah Kabupaten Banyumas, sedangkan pedesaan Kawasan Agrowisata di Kecamatan Karangreja dan Kawasan Agrowisata di Kecamatan Kutasari mewakili wilayah Kabupaten Purbalingga.
Pemilihan keempat lokasi ini dilakukan dengan teknik purposive sampling area.

Jenis data yang dibutuhkan dalam penelitian mencakup data primer dan data sekunder baik yang bersifat kualitatif maupun kuantitatif. Data primer dikumpulkan dengan teknik wawancara mendalam, observasi dan focus group discussion (FGD). Data sekunder dikumpulkan dengan teknik penelusuran diiringi analisis data sekunder terkait. Sumber data mencakup: subjek informan, subjek responden dan subjek informan kunci. Subjek informan ditetapkan dengan teknik purposive sampling. Adapun subjek responden ditentukan dengan teknik simple random sampling. Subjek informan kunci dipilih dengan teknik bola salju bergulir untuk mewakili keberadaan tokoh masyarakat desa (opinion leader), aparat pemerintahan desa dan pihak pengelola kawasan agrowisata. Kesemua data yang dikumpulkan diolah dengan teknik kualitatif dan kuantitatif. Setelah diolah, data kualitatif dianalisisis dengan memanfaatkan Interactive Model of Analysis (Miles and Huberman, 1991). Analisis data bersifat kuantitatif dilakukan dengan teknik statistik deskriptif. Data yang telah dianalisis disajikan dalam uraian deskriptif kualitatif dilengkapi penjelasan kuantitatif dan disusun secara sistematis.

\section{Permasalahan Hubungan Sosial dan Solusinya}

Pemaknaan terhadap pemberdayaan lebih spesifik mengarah pada peningkatan kemampuan, kapasitas, produktivitas, kreativitas dan kemandirian masyarakat untuk mendapatkan kesempatan yang lebih besar dalam mengakses sekaligus mengontrol berbagai sumber kehidupan penting. Lebih terperinci, Stewart (1994) menyatakan bahwa empowerment is quite simple, a highly practical and productiveway to get the best from your self and your staff. Dengan demikian, dapat ditegaskan pemberdayaan sesungguhnya bukan merupakan tujuan pembangunan melainkan alat untuk mencapai tujuan yang ditargetkan. Peningkatan daya keinovatifan dalam proses pemberdayaan dapat dilakukan melalui rangkaian tahapan berikut: (1) Tahap penyadaran; (2) Tahap penumbuhan minat dan ketertarikan; (3) Tahap penilaian; (4) Tahap mencoba dalam skala kecil; dan (5) Tahap menerapkan solusi terpilih untuk menyelesaikan permasalahan sosial yang dihadapi.

Guna menghindari bias tujuan, pemberdayaan perlu ditafsirkan sebagai suatu proses atau mekanisme yang menggerakkan partisipasi aktif individu, kelompok dan masyarakat hingga mumpuni menyelesaikan permasalahan sendiri. Penetapan tujuan pemberdayaan perlu disesuaikan permasalahan dan kebutuhan 
masyarakat sehingga menurut Wrihatnolo dan Dwidjowijoto (2007) bahwa teori pemberdayaan mengasumsikan bahwa: (1) Pemberdayaan akan berbeda bentuk untuk orang yang berbeda; (2) Pemberdayaan akan berbeda untuk konteks yang berbeda; dan (3) Pemberdayaan berfluktuasi atau berubah seiring perjalanan waktu.

Bertolak dari pentingnya memahami ketiga asumsi diatas maka dalam setiap upaya pemberdayaan dibutuhkan strategi yang menghendaki dilaksanakannya pemihakan pada kelompok masyarakat tertentu. Pemihakan di sini dimaksudkan untuk memberi kesempatan lebih besar kepada kelompok masyarakat yang lemah agar mendapat perlindungan dan jaminan yang berarti bagi peningkatan kualitas sumberdaya lokal yang dimiliki.

Pada setiap proses pemberdayaan dituntut penguatan masyarakat dalam peningkatan kapasitas, kemandirian dan kreativitas mengelola berbagai kegiatan produktif. Pelaksanaan proses pemberdayaan masyarakat desa tidak dapat dilakukan secara temporal namun perlu berkelanjutan. Beberapa hal penting lain yang perlu diperhatikan dalam pemberdayaan masyarakat desa menurut Triharso (2010) ialah mengembangkan: prospek usaha dan akses pasar, jiwa kewirausahaan, kelembagaan ekonomi rasional dan kemitraan usaha.

Pemikiran tentang pentingnya pemihakan dalam pemberdayaan masyarakat relevan dengan penjelasan Chambers (1987) yang menegaskan bahwa dalam pembangunan masyarakat di pedesaan pola pendekatan yang dilakukan semestinya dibalik yakni bertolak dari belakang. Artinya, pemberdayaan dimulai dari langkah memprioritaskan kaum miskin atau mendahulukan kelompok masyarakat yang terakhir, terbelakang dan terpinggirkan. Basis pemberdayaan terletak pada lingkup permasalahan dan cakupan kebutuhan riil masyarakat desa disertai kondisi ketersediaan potensi sumberdaya lokal.

Diseminasi model merupakan salah satu tahap penting yang dilalui dalam proses pemberdayaan masyarakat termasuk yang mukim di pedesaan Kawasan Agrowisata Baturaden dan Cilongok, Kabupaten Banyumas beserta Kawasan Agrowisata Karangreja dan Kutasari, Kabupaten Purbalingga. Kegiatan diseminasi pada penelitian ini adalah proses penyebarluasan informasi model pemberdayaan yang diorientasikan dengan memanfaatkan berbagai potensi sumberdaya lokal. Tujuan diseminasi model dimaksudkan untuk meningkatkan kesadaran masyarakat desa sebagai

Tabel 1

Pola Hubungan Sosial Masyarakat Desa dengan Pertukaran Ekstrinsik dan I ntrinsik

\begin{tabular}{|c|c|c|}
\hline $\begin{array}{c}\text { Pola Hubungan } \\
\text { Sosial }\end{array}$ & $\begin{array}{c}\text { Motif Hubungan } \\
\text { Sosial }\end{array}$ & Kepentingan Hubungan Sosial \\
\hline \multirow[t]{2}{*}{$\begin{array}{l}\text { Ekstrinsik } \\
\text { (antara anggota } \\
\text { masyarakat desa } \\
\text { dengan pihak luar) }\end{array}$} & Ekonomi & $\begin{array}{l}\text { Memperoleh imbalan berupa nilai rupiah dari pihak } \\
\text { lainMemperoleh simpatik dari pihak lain agara tertarik membeli } \\
\text { produk agrowisata yang ditawarkanAda proses transaksi, } \\
\text { negoisasi dan tawar menawar antar pelaku hubungan } \\
\text { sosialMemberi manfaat ekonomi bagi pihak yang } \\
\text { berhubunganMendukung kegiatan produktif di pasar } \\
\text { agrowisataPenguatan hubungan bisnis petani dan pedagang } \\
\text { pelanggan }\end{array}$ \\
\hline & Sosial & $\begin{array}{l}\text { J alinan persaudaraan/pertemanan antara petani dan warga } \\
\text { desa lain dengan pengelola agrowisataSaling bantu dalam } \\
\text { kegiatan sosial budaya dan pemeliharaan kebersihan lingkungan } \\
\text { desa (iuran jimpitan). }\end{array}$ \\
\hline \multirow[t]{2}{*}{$\begin{array}{l}\text { Intrinsik(antara } \\
\text { sesama anggota } \\
\text { masyarakat desa) }\end{array}$} & Sosial & $\begin{array}{l}\text { Memperoleh pengertian, pemahaman, kepedulian, perhatian } \\
\text { dan bentuk sosial reward lainMempererat solidaritas dan } \\
\text { kolektivitas kerja dalam kelompok taniMenjaga kerukunan antar } \\
\text { warga masyarakat desaMenguatkan fungsi kelembagaan } \\
\text { sosialPertukaran pengalaman kerja produktif di pasar } \\
\text { agrowisataPenguatan rasa pertemanan dan persahabatan }\end{array}$ \\
\hline & Ekonomi & $\begin{array}{l}\text { Berbagi informasi pasar produk agrowisata Sewa menyewa } \\
\text { lahan pertanianTransaksi pembayaran upah tenaga kerja di } \\
\text { pasar kawasan agrowisata Persaingan bisnis (penetapan harga) }\end{array}$ \\
\hline
\end{tabular}


subjek sekaligus kelompok target pemberdayaan agar bersedia menerapkan ragam acuan kegiatan produktif dan kreatif yang termuat dalam materi model pemberdayaan. Diseminasi juga memberi ruang gerak bagi anggota masyarakat desa di kawasan agrowisata untuk ikut berpartisipasi aktif menyusun kebutuhan strategis dan permasalahan riil dalam upaya menemukan alternatif solusi yang lebih tepat guna dan tepat sasaran.

Dalam setiap diseminasi model pemberdayaan, hubungan sosial selalu memegang fungsi penting. Penjalinan hubungan sosial seringkali dibentuk berdasarkan kepentingan subjektif yang diwarnai orientasi diri dan orientasi kolektif. Pada orientasi diri, hubungan sosial dijalin dengan lebih mengutamakan kepentingan diri sendiri. Adapun pada orientasi kolektif yang dikedepankan kepentingan kebersamaan. Pada berbagai bentuk hubungan sosial masyarakat desa yang diteliti ditemukan kedua jenis orientasi ini saling menguatkan untuk pencapaian ragam kepentingan anggota masyarakat dan pihak lain. Meski demikian, kadang kala terjadi dilema pada hubungan sosial ketika orientasi diri berjalan tak seiring dengan orientasi kolektif.

Orientasi subjektif kolektif pada hubungan sosial masyarakat desa di lokasi penelitian bermula dari kesadaran akan pentingnya mempertahankan kebersamaan. Kesadaran kolektif (collective conscience) berfungsi sebagai pintu pembuka agar pada diri seseorang tumbuh keinginan mengadakan hubungan sosial dengan orang lain secara berkelompok (collective representation). Pada diseminasi model, strategi yang diterapkan ternyata mampu meningkatkan minat sekaligus kesadaran kolektif masyarakat desa di kawasan Agrowisata Baturaden, Cilongok, Karangreja dan Kutasari.

Hubungan sosial mencerminkan kejadian pertukaran sosial berupa ragam tindakan masyarakat desa dalam pengelolaan agrowisata. Orientasi hubungan sosial tergantung pada reaksi atau yang diberikan masyarakat desa terhadap orang lain (pengelola/pengunjungkawasan agrowisata) atau sebaliknya orang lain terhadap keberadaan masyarakat desa. Pertukaran sosial berlanjut bilamana reaksi atau respon sesuai harapan; terhenti bila reaksi atau respon tidak sesuai dengan keinginan pihak yang saling berhubungan. Hubungan sosial pada masyarakat di keempat kawasan agrowisata menunjukkan pola pertukaran ekstrinsik dan intrinsik. Pada Tabel 1 tercantum penjelasan hubungan sosial pada masyarakat desa di kawasan agrowisata yang diteliti dengan pola pertukaran ekstrinsik dan intrinsik.

Pada hubungan sosial dengan kedua bentuk pertukaran yakni ekstrinsik dan intrinsik (Tabel 1 ) baik bermotif ekonomi maupun sosial khususnya yang berkenaan dengan diseminasi model pemberdayaan tak jarang ditemukan berbagai permasalahan yang merintangi pencapaian kepentingan antar pihak. Menurut mayoritas informan, anggota masyarakat desa di kawasan agrowisata senantiasa berupaya menyelesaikan rangkaian permasalahan sesuai kemampuan. Kelemahan dan mungkin juga sebagai kelebihan hubungan sosial instrinsik sesama warga di pedesaan tampak dari data yang tertuang dalam Tabel 1 yang menunjukkan bahwa interaksi sosial warga masyarakat lokal lebih cenderung pada motif sosial. Sebaliknya proporsi motif ekonomi dengan warga luar desa lebih menyolok dibanding dengan motif sosialnya. Hal ini juga mengindikasikan bahwa ada perlakuan yang tidak sama dalam hubungan sosial dengan pihak luar dibanding dengan sesama anggota komunitas lokal. Namun yang jelas mereka memiliki motif pertukaran dengan jenis pertukaran yang berbeda.

Pertukaran dengan pihak luar lebih bersifat ekonomik-kalkulatif, sedangkan pertukaran dengan warga masyarakat local lebih berwatak subyektifemosional dan sosial. Warga desa pada umumnya mementingkan hubungan sosial jika berhubungan dengan sesama warga masyarakat lokal. Kendati demikian, warga desa bukan berarti tidak rasional. Hanya saja dalam berbagai jalinan hubungan sosial antar warga desa lebih menggunakan logika sosial dari pada logika ekonomi. Dalam hubungan sosial berpola intrinsik, warga bisa saja mengorbankan kepentingan ekonominya. Namun walau begitu tidak menafikan kepentingan-kepentingan ekonominya. Hal ini sering terungkap dalam ungkapan sederhana: "tuna sathak bathi sanak" (artinya rugi secara ekonomis, namun bertambah teman dan atau saudara). Meski demikian, di Kawasan Agrowisata Baturaden yang sudah mulai menunjukkan perubahan social dengan gejala masyarakat yang tengah menuju ciri 'mengkota' tentu saja implementasi slogan itu bisa bergeser perlahan. Terlebih dengan adanya intervensi komersialisasi ekonomi dan meningkatnya harga berbagai komoditas yang menjadi kebutuhan hidup sehari-hari. Beberapa permasalahan hubungan sosial dan solusi yang dilakukan anggota masyarakat desa dalam proses diseminasi model pemberdayaan terinci pada Tabel 2.

Meski rawan dirintangi berbagai permasalahan seperti tertera pada Tabel 2, berbagai pihak yang ditempatkan pada posisi kelompok internal dan eksternal berusaha menjalin ragam bentuk hubungan sosial guna menmperoleh kepentingan masing-masing. Permasalahan yang berkenaan dengan penyebarluasan informasi yang tidak merata diakui mayoritas (79 persen) subjek informan menjadi perintang yang masih sulit diatasi sesuai kebutuhan. Terkadang pada satu bentuk hubungan sosial terdapat pertukaran ekonomi dan 
sosial sekaligus dalam waktu bersamaan sehingga terjadi tumpang tindih kepentingan.

Pada pengelolaan agrowisata yang berbasis sumberdaya lokal untuk pemberdayaan masyarakat desa diantara berbagai pihak sudah memiliki kesadaran subjektif untuk saling memberi sesuatu yang berharga sosial seperti: pengertian, pemahaman, kepedulian dan perhatian. Di balik sosial reward tersebut, realitas sesungguhnya menunjukkan tersimpan potensi ekonomi menuju pertukaran ekstrinsik. Hubungan dagang dengan pertukaran ekstrinsik yang sudah berlangsung terlalu lama umpama antara pelanggan dengan pengrajin sapu glagah di Karangreja, Purbalingga akhirnya membentuk interaksi menuju pertemanan dan persahabatan seperti pada pertukaran intrinsik seperti dijelaskan pada Tabel 1.

Bentuk hubungan sosial antar berbagai pihak dalam pengelolaan agrowisata dapat menimbulkan proses sosial yang bersifat asosiatif dan disosiatif. Bentuk proses sosial asosiatif dicirikan dari kedekatannya dengan kerjasama sedang proses sosial disosiatif mencirikan pada kejadian pertentangan dan konflik. Memang apa yang disampaikan ini sebatas kecenderungan yang ditemukan di lapangan. Kedua fenomena ini saling melengkapi agar penjelasan tidak timpang dan hanya ditinjau dari aspek stabilitas saja. Dengan demikian, aspek dinamika masyarakat di kawasan agrowisata dapat terungkap secara lebih natural, seimbang dan tidak hanya satu sisi (one sided), tetapi merupakan satu kesatuan yang terintegrasi. Penjelasan fenomena dari kedua proses ini pada masyarakat desa yang diteliti cenderung terjadi hubungan yang kontradiktif yakni di satu sisi potensial memunculkan suasana harmonis sementara di sisi lain konflik. Alasan yang mendasari argumen ini cukup berarti. Dalam hubungan sosial antar lapisan dan antar strata atau bahkan antar sub kultur masyarakat desa berbagai kenyataan bisa terjadi. Jika dianalisis dengan menggunakan paradigma positivisme maka sistem sosial secara teratur menuju titik kestabilan dan bahwa setiap aktor sosial berkesempatan melakukan adaptasi sosial (Santoso, 1994). Akan tetapi, jika masyarakat dinilai tidak stabil maka adaptasi sosial tidak cukup untuk menengahi. Lebih jauh lagi perlu dilakukan reorganisasi, restrukturisasi dan perubahan sistem atau tatanan sosial. Tentu saja, berdasarkan tingkat kedalaman permasalahan yang terjadi sampai kondisi kembali menuju ekuilibrium atau keseimbangan.

Warga desa yang berusaha menekuni berbagai kegiatan produktif dan kreatif di bidang agrowisata di pedesaan sering mengalami kegamangan terutama sewaktu tengah menghadapi peristiwa: kelangkaan pasar, penggusuran lokasi unit kerja, penurunan harga produk, ketakterjaminan pasokan bahan baku, kerusakan teknologi, serangan hama dan penyakit tanaman, kegagalan produksi/panen, kemacetan pembayaran uang hasil penjualan produk, jumlah

Tabel 2

Permasalahan Hubungan Sosial dan Solusi dalam Diseminasi Model Pemberdayaan

\begin{tabular}{|c|c|c|}
\hline Ragam Permasalahan Hubungan Sosial & Solusi & $(\%)$ \\
\hline $\begin{array}{l}\text { Ketertinggalan informasi mengenai kecenderungan } \\
\text { harga pasar dan jenis produk tertentu yang dihasilkan } \\
\text { hingga kurang sesuai permintaan pasar agrowisata. }\end{array}$ & $\begin{array}{l}\text { Berbagi informasi harga dengan warga } \\
\text { lain melalui media komunikasi antar per- } \\
\text { sonal dan antar kelompok. Mengikuti } \\
\text { fluktuasi harga di pasar agrowisata } \\
\text { setempat. }\end{array}$ & 25 \\
\hline $\begin{array}{l}\text { Benturan kepentingan bermotif ekonomi dengan } \\
\text { sesama warga desa. Permasalahan ini biasanya terjadi } \\
\text { diantara sesama warga pedagang aneka produk (sou- } \\
\text { venir, makanan, minuman, buah, sayuran, hasil kerajinan } \\
\text { lain) di pasar wisata. Rebutan lokasi untuk dagang sering } \\
\text { terjadi antar sesama pedagang di kawasan agrowisata. }\end{array}$ & $\begin{array}{l}\text { Membuat perjanjian penempatan lokasi } \\
\text { berdagang sesuai kesepakatan } \\
\text { bersama.Beberapa warga desa mengalah } \\
\text { menjadi pedagang keliling di kawasan } \\
\text { agrowisata. }\end{array}$ & 38 \\
\hline $\begin{array}{l}\text { Benturan kepentingan bermotif sosial lingkungan antara } \\
\text { warga desa dengan pengelola kawasan agrowisata. } \\
\text { Tidak jarang, lokasi dagang warga desa digusur dari } \\
\text { kawasan agrowisata oleh petugas ketertiban kawasan } \\
\text { agrowisata dengan alas an untuk kenyamanan, } \\
\text { ketertiban, keindahan dan keamanan pengunjung. }\end{array}$ & $\begin{array}{l}\text { Penyediaan lokasi alternatif bagi warga } \\
\text { desa yang tergusur.Pengelola kawasan } \\
\text { agrowisata mempersiapkan lokasi khusus } \\
\text { bagi warga desa untuk berdagang aneka } \\
\text { produk. }\end{array}$ & 44 \\
\hline $\begin{array}{l}\text { Penyebarluasan informasi teknologi produksi untuk } \\
\text { menghasilkan berbagai produk agrowisata belum merata. } \\
\text { Sebagai konsekwensi, hubungan sosial yang terjalin } \\
\text { renggang karena terdapat kesenjangan informasi. }\end{array}$ & $\begin{array}{l}\text { Berusaha memelihara rasa saling percaya } \\
\text { (trust) diantara sesama pihak yang } \\
\text { berhubungan. }\end{array}$ & 79 \\
\hline
\end{tabular}


konsumen yang berwisata menurun dan reduksi daya dukung lahan serta pencemaran lingkungan alam desa. Rangkaian persoalan tersebut dapat diselesaikan melalui upaya membangun jaringan bisnis produktif di tingkat keluarga pada masyarakat desa dan mengembangkan kerjasama kelembagaan ekonomi (Muldjono, 2010). Berbagai pelatihan dan pendidikan tak formal yang dapat meningkatkan kesadaran, pengetahuan dan ketrampilan para anggota keluarga ditengahtengah masyarakat desa dalam mengelola agrowisata perlu diselenggarakan secara rutin dan intensif hingga memunculkan kemandirian dalam berusaha secara produktif dan kreatif. Pekerjaan berusahatani untuk menyediakan aneka jenis buah-buahan dan sayuran di pasar agrowisata menjadi alternatif pola nafkah yang paling diminati anggota masyarakat desa yang diwawancarai di keempat kawasan lokasi penelitian. Sebagian warga lainnya menekuni pekerjaan produktif sebagai: pengrajin/pedagang souvenir, pengrajin/ pedagang makanan/minuman, tukang parkir, petugas kebersihan/keamanan, petugas pemungut retribusi pasar agrowisata, pedagang, penyedia jasa ojek, petugas/makelar tiket masuk, pemandu/ guide, penyedia jasa pulsa, seniman jasa gelar seni budaya dan lainnya.

Pola nafkah yang ditekuni mayoritas anggota masyarakat mengalami diversifikasi secara temporal. Beberapa orang anggota masyarakat yang menjadi informan penelitian mengungkapkan dalam sehari bisa menekuni pola nafkah produktif lebih dari satu atau dua jenis pekerjaan. Pagi hari bertani di sawah/kebun, siang hari berdagang buah dan sayuran di pasar agrowisata dan malam hari menjadi petugas keamanan di beberapa sarana fasilitas kawasan agrowisata.

Dalam menjalin ragam bentuk hubungan sosial, masyarakat desa di Kawasan Agrowusata Baturaden, Cilongok, Karangreja dan Kutasari berusaha berperilaku yang mengarah pada pembentukan proses sosial asosiatif. Masyarakat petani dan pedagang yang ada di keempat kawasan agrowisata cenderung mempertahankan pola laten untuk memelihara ketertiban dan keharmonisan kehidupan sosial. Proses sosial asosiatif terutama terkait kerukunan warga dijaga dengan langgeng melalui penguatan hubungan sosial berpola internal

Mayoritas masyarakat merasa puas dengan hasil pekerjaan yang ditekuni sehari-hari. Hanya sedikit yang mengeluh tak puas atas pendapatan yang diperoleh dari pengelolaan usaha di bidang agrowisata. Beberapa alasan yang dikemukakan subjek responden mendasari rasa ketidakpuasan warga desa tertera pada Gambar 1.

Kerjasama saling menguntungkan yang tetap dipertahankan diantara antar warga masyarakat untuk saling tukar pengalaman dalam mengelola usaha produktif. Mereka lebih banyak saling isi dan membina kekompakan berusaha dan tidak saling melanggar hak dan kewajiban para pelaku ekonomi yang lain. Kecenderungan seperti ini bukan berarti menafikan atau meniadakan

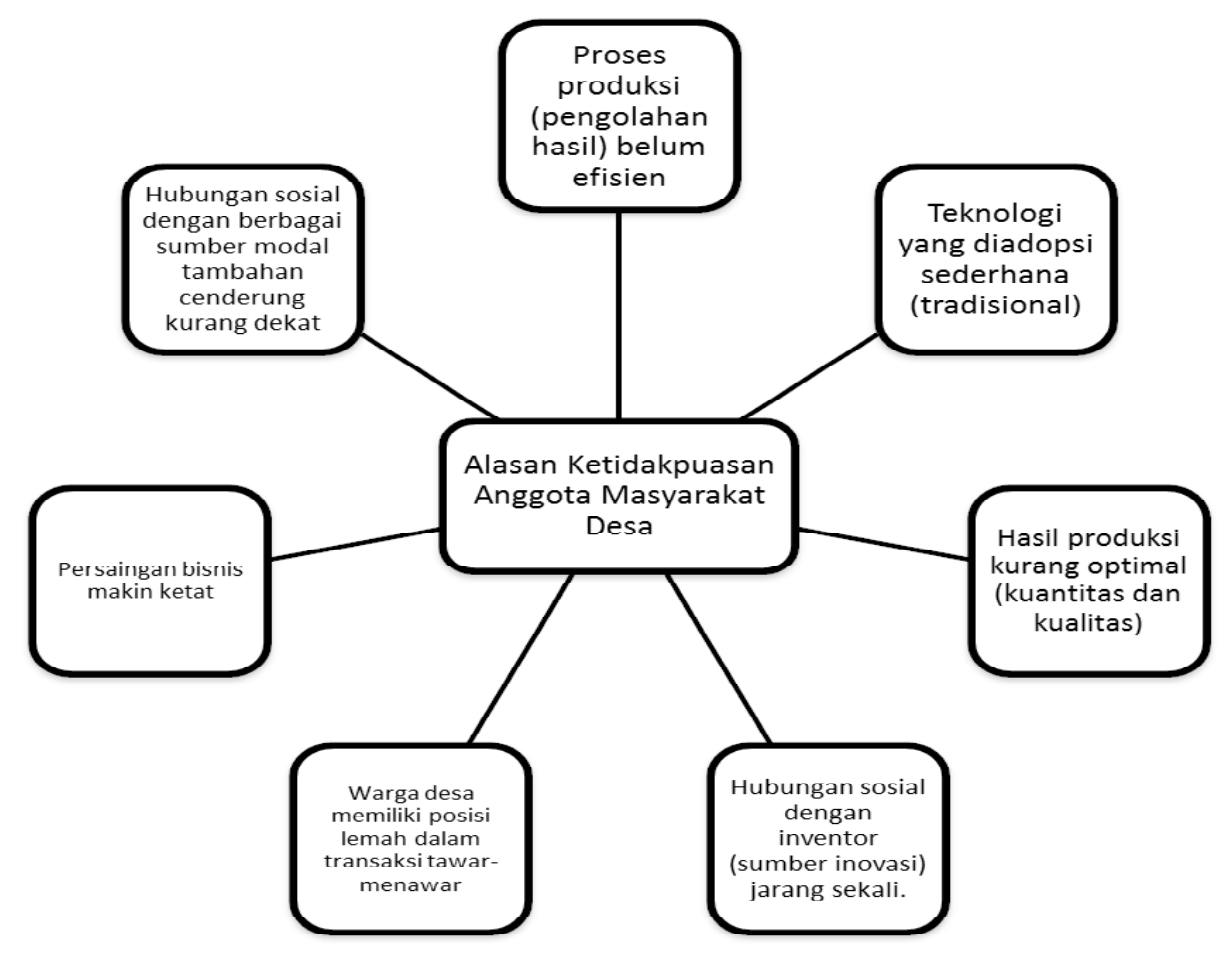

Gambar 1. Beberapa Alasan Ketidakpuasan Masyarakat dalam Pengelolaan Agrowisata 
kondisi konflik sosial yang berlangsung. Konflik selalu ada saja dalam setiap kesempatan. Namun, berdasarkan pengamatan konflik yang berlangsung tidak sampai merubah sistem sosial dan sistem politik. Konflik yang ada ditanggapi sebagai bentuk adaptasi baru yang tidak mengkoyak sistem sosial yang dijaga keberadaannya oleh masyarakat desa sebagai aktor sosial. Hal ini dapat dilihat, misalnya: ketegangan dengan buruh tani saat pesanan atau permintaan konsumen terhadap buah dan sayuran sebagai produk andalan souvenir agrowisata meningkat di musim liburan, ketegangan sosial muncul seketika khususnya sewaktu ada tuntutan kenaikan gaji buruh tani. Namun kondisi yang demikian dapat diantisipasi melalui cara musyawarah bersama dengan memanfaatkan pendekatan kekeluargaan yang persuasif.

\section{Keberfungsian Hubungan Sosial dalam Diseminasi Model Pemberdayaan}

Hubungan sosial pada proses diseminasi model pemberdayaan masyarakat desa melalui pengelolaan agrowisata terjalin dengan komunikatif bilamana kepentingan yang dipertukarkan antar pihak bersifat mutualism. Pada proses diseminasi model, baik di pedesaan Kawasan Agrowisata Baturaden, Cilongok, Karangreja dan Kutasari ditemukan beberapa bentuk hubungan sosial asosiatif untuk kepentingan pengelolaan berbagai pola nafkah produktif. Jalinan hubungan sosial ini mempunyai keberfungsian penting pada proses peningkatan kesadaran dan kemampuan anggota masyarakat desa dalam pengelolaan agrowisata.

Keberfungsian hubungan sosial pada diseminasi model pemberdayaan tidak hanya terbatas menjalin kontak dan komunikasi penyampaian informasi tertentu yang terkait kegiatan produktif. Keberfungsian lain yang dirasakan warga desa di kawasan pedesaan dari jalinan hubungan sosial erat tautannya dengan pembentukan pola perilaku yang kondusif dalam pengelolaan agrowisata. Penjelasan lebih lanjut mengenai keberfungsian hubungan sosial pada diseminasi model pemberdayaan terperinci pada Tabel 3.

Keluwesan hubungan sosial pada masyarakat desa di keempat kawasan agrowisata yang diteliti tidak terlepas dari peran beberapa orang fasilitator pemberdayaan. Fasilitator menjadi motor penggerak keluwesan hubungan

Tabel 3

Keberfungsian Hubungan Sosial pada Diseminasi Model Pemberdayaan

\begin{tabular}{|l|l|}
\hline \multicolumn{1}{|c|}{ Keberfungsian Hubungan Sosial } & \multicolumn{1}{c|}{ Domain Perilaku } \\
\hline $\begin{array}{l}\text { Kesadaran warga terdorong untuk menciptakan dan } \\
\text { mengembangakan berbagai lapangan kerja sendiri } \\
\text { yang berhubungan dengan pengelolaan agrowisata } \\
\text { berbasis sumberdaya lokal. J enis lapangan kerja yang } \\
\text { cenderung diminati warga adalah home industry } \\
\text { dengan berbagai produk, berbahan baku sumberdaya } \\
\text { lokal. Terutama hasil pertanian, kehutanan, perikanan } \\
\text { dan peternakan. }\end{array}$ & $\begin{array}{l}\text { Kesadaran, kemauan dan motivasi melakukan } \\
\text { diversikasi pola nafkah produktif dalam pengelolaan } \\
\text { peningatan yang signifikan. }\end{array}$ \\
$\begin{array}{l}\text { Mengubah sikap warga yang semula hanya apatis } \\
\text { (nrimo dan pesimis) menjadi produktif dan kreatif. } \\
\text { Selain itu, juga mengurangi ketergantungan kepada } \\
\text { pihak lain. }\end{array}$ & $\begin{array}{l}\text { Pengetahuan dan ketrampilan anggota masyarakat } \\
\text { desa dalam pengembangan pola nafkah produktif } \\
\text { kreatif meningkat. }\end{array}$ \\
$\begin{array}{l}\text { Produk dan jasa yang dihasilkan warga desa semakin } \\
\text { beraneka dan bargaining position menguat untuk } \\
\text { ditawarkan di kawasan agrowisata. }\end{array}$ & $\begin{array}{l}\text { Kemampuan dalam berkreasi menghasilkan ragam } \\
\text { produk meningkat. }\end{array}$ \\
$\begin{array}{l}\text { Kemauan dan kemampuan berwirausaha meningkat } \\
\text { diindikasikan kondisi naluri bisnis yang mulai tertarik } \\
\text { menyesuaikan desain, bentuk dan jumlah produk } \\
\text { dengan kecenderungan permintaan konsumen di } \\
\text { pasar agrowisata. }\end{array}$ & $\begin{array}{l}\text { Kesadaran, kemauan, pengetahuan } \\
\text { ketrampilan berwirausaha terdorong untuk } \\
\text { memperhatikan kecenderungan pasar agrowisata. }\end{array}$ \\
$\begin{array}{l}\text { Memudahkan anggota masyarakat desa di kawasan } \\
\text { pasar dan teknologi. }\end{array}$ & $\begin{array}{l}\text { Kemampuan berkarya secara produktif dengan } \\
\text { memanfaatkan sumberdaya lokal meningkat. }\end{array}$ \\
\hline
\end{tabular}


sosial masyarakat desa di kawasan agrowisata agar aktif memanfaatkan potensi sumberdaya lolal dalam pengelolaan agrowisata yang berbasis pro poor. Tugas utama fasilitator pemberdayaan adalah mengembangkan pembelajaran bagi masyarakat lokal untuk membangun tingkat kemandirian dalam menyelesaikan masalah yang mereka hadapi. Keberadaan fasilitator ini memang penting, Wijaya (2010) mengemukakan bahwa tugas utama lainnya seorang fasilitator pemberdayaan adalah mengembangkan pembelajaran bagi masyarakat lokal untuk membangun tingkat kemandirian dalam menyelesaikan masalah yang dihadapi.

Kendatipun begitu, kemampuan fasilitator bukanlah segala-galanya dalam optimalisasi hubungan sosial bagi pemberdayaan masyarakat desa di kawasan agrowisata. Pemilihan media yang digunakan dan isi pesan pemberdayaan yang ditawarkan serta lingkup konteks sosial turut menjadi penentu lain bagi keberhasilan fasilitator dalam membangun relasi sosial. Kemampuan fasilitator meramu beberapa faktor tersebut menjadi jembatan (bridger the gap) untuk mengatasi kendala komunikasi yang terjadi, sehingga model pemberdayaan terjalin integratif dan sinergis. Kemampuan fasilitator untuk membawakan dirinya sebagai tipe ideal (ideal type) sebagai mediasi berjalan lancar jikalau masyarakat audiens mendukung peran dirinya. Dalam banyak kasus peran fasilitator terganggu terutama saat citra tipe ideal dipandang tidak sesuai dengan sentiment komunitas.

Kemanfaatan model pemberdayaan masyarakat yang dibangun akan memiliki daya yang lebih besar bila hubungan sosial yang terjalin antara fasilitator, media dan masyarakat pengguna berjalan sinergis. Penguatan hubungan sosial asosiatif yang memuat ide pemberdayaan diyakini masyarakat desa mampu memberi kemanfaatan riil bagi pengembangan kemampuan mengelola agrowisata berbasis sumberdaya lokal. Kesulitan hubungan sosial terjadi ketika ada sekelompok orang yang tidak rela jikalau pengelolaan sumberdaya komunal sulit membagi mana yang telah memberikan korbanan (cost) dan mana yang sekedar berpartisipasi dengan tingkatan sambil lalu saja (Wrihatnolo dan Dwidjowijoto, 2007).

Tabel 4

Hasil Diseminasi Model Pemberdayaan Masyarakat Desa

\begin{tabular}{|c|c|}
\hline Tahapan Diseminasi & Perubahan Perilaku \\
\hline $\begin{array}{l}\text { Memberi perhatian atas } \\
\text { penyebaran informasi model } \\
\text { pemberdayaan. }\end{array}$ & $\begin{array}{l}\text { Perubahan pada pengetahuan dan sikap yang responsive dan ingin } \\
\text { tahun struktur dan isi model. Beberapa informan secara aktif membahas } \\
\text { serius kelayakan fungsi dari beberapa unsur pembangun model. }\end{array}$ \\
\hline $\begin{array}{l}\text { Memahami struktur dan isi model } \\
\text { pemberdayaan. }\end{array}$ & $\begin{array}{l}\text { Peningkatan pengetahuan dan sikap tentang fungsi dan kemanfaatan } \\
\text { setiap unsur pembangun struktur formulasi model. }\end{array}$ \\
\hline $\begin{array}{l}\text { Menilai kelebihan dan kelemahan } \\
\text { model pemberdayaan. }\end{array}$ & $\begin{array}{l}\text { Berbagai kelebihan dan keunggulan model terdeteksi informan dengan } \\
\text { bijaksana. Terproyeksi media cetak dan lisan untuk promosi dan } \\
\text { peningkatan komunikasi usaha produktif dalam pengelolaan agrowisata } \\
\text { ramah lingkungan. }\end{array}$ \\
\hline $\begin{array}{l}\text { Merangsang selektivitas dan } \\
\text { daya kritisi masyarakat terhadap } \\
\text { struktur dan isi model } \\
\text { pemberdayaan }\end{array}$ & $\begin{array}{l}\text { Informan yang mewakili kepentingan masyarakat pedesaan di kawasan } \\
\text { agrowisata sebagian bisa menilai secara kritis dan dapat merespon isi } \\
\text { yang termaktub dalam formulasi model. Mereka juga aktif memberikan } \\
\text { berbagai kritik dan revisi yang membangun kelayakan fungsi model. }\end{array}$ \\
\hline $\begin{array}{l}\text { Menyebarkan informasi } \\
\text { kemanfaatan praktis dan teoritis } \\
\text { model pemberdayaan kepada } \\
\text { warga desa pengguna }\end{array}$ & $\begin{array}{l}\text { Ada sebagian informan yang mewakili masyarakat yang telah mencoba } \\
\text { model secara parsial. Walaupun belum seutuhnya namun kemanfaatan } \\
\text { model telah teruji secara praktis. }\end{array}$ \\
\hline $\begin{array}{l}\text { Menyesuaikan model } \\
\text { pemberdayaan dengan nilai dan } \\
\text { norma sosial masyarakat }\end{array}$ & $\begin{array}{l}\text { Menerapkan dan bersikap adaptif terhadap keluwesan formulasi model } \\
\text { sesuai aspirasi dan kebutuhan serta reaksi penerimaan lingkungan sosial } \\
\text { di pedesaan kawasan agrowisata. }\end{array}$ \\
\hline $\begin{array}{l}\text { Menemukan umpan balik } \\
\text { masyarakat pedesaan terhadap } \\
\text { informasi formulasi model } \\
\text { pemberdayaan }\end{array}$ & $\begin{array}{l}\text { Umpan balik sebagian bernilai positif dan sebagian lain negatif. Umpan } \\
\text { balik negative dijadikan bahan pertimbangan untuk merevisi formulasi } \\
\text { model. Pencaharian umpan balik dilakukan dengan menerapkan media } \\
\text { komunikasi dan kontak personal. }\end{array}$ \\
\hline
\end{tabular}


Persoalan dalam hubungan sosial ini tentu saja jawabannya adalah memberikan sanksi sosial yang memadai, sehingga rasa keadilan sosial menguat. Namun perlu diketahui, bahwa perkembangan agrowisata memiliki kesamaan dengan pariwisata pada umumnya mencakup tiga dimensi, yakni: kultural, politik dan bisnis (Usman, 2006). Hal ini mengandung makna bahwa dengan adanya agrowisata, maka semakin tingginya interaksi antar kebudayaan, munculnya kesenjangan dan persahabatan dan meningkatnya interaksi bisnis. Tentu saja hal ini akan meningkatkan disparitas sosial dan penerapan norma sosial menjadi semakin permisif. Dampaknya pada hubungan sosial manusia semakin kalkulatif dan kontraktual. Hal ini dapat dibandingkan antara keempat lokasi agrowisata di dua kabupaten terbukti bahwa berbagai pola hubungan sosial yang kalkulatif tampak di kawasan yang semakin mengkota (Kawasan Agrowisata Baturaden). Kontak antara dua budaya ekonomi yang berbeda (ekonomi tradisional versus ekonomi modern) menjadikan sederet hubungan sosial dengan sifat yang berbeda (Wijaya, 2010).

Hubungan sosial yang berorientasi kesadaran kolektif masih dibutuhkan dalam proses diseminasi model pemberdayaan masyarakat desa di keempat kawasan agrowisata. Akibat dari kohesi sosial yang lebih kuat di daerah pedesaan, maka kesadaran kolektif untuk implementasi model lebih mantap. Hal tersebut lebih mudah terjadi jika fasilitator bersama agen pemberdayaan lain dapat menyentuh sentimen komunitas masyarakat lokal. Bagi sifat kohesi yang lemah di pedesaan berwajah kekotaan secara khusus memerlukan konsep pemberdayaan yang tidak semata mengandalkan kolektivitas. Akan tetapi, lebih pada pilihan rasional dengan lebih memanfaatkan hubungan sosial yang bersifat kalkulatif transaksional dengan senantiasa menekankan pada nilai kegunaan ekonomis bagi masyarakat untuk mengadopsi model yang telah dirancang.

Berdasarkan hasil pengamatan, keberfungsian hubungan sosial dalam proses diseminasi model pemberdayaan ternyata tidak selalu berjalan lancar. Upaya yang dimanfaatkan untuk menjalin hubungan sosial komunikatif ialah memilih dan memadukan beberapa metode dan media penyampaian informasi secara variatif. Hubungan sosial pada diseminasi akhirnya mampu mengumpulkan dan menyaring umpan balik yang diberikan warga desa terhadap kelayakan fungsi model. I nformasi mengenai hasil diseminasi model tercantum pada Tabel 4.

Dari hasil diseminasi model pemberdayaan seperti yang teramati pada Tabel 4 diperoleh beragam umpan balik yang diberikan warga desa agar dapat dicapai kelayakan fungsi model. Daya selektif untuk penyempurnaan model ditentukan justeru oleh masukan berupa umpan balik negatif (negative feedback) bagi penyempurnaan model yang dirancang dan bukan semata dari umpan balik positif (positive feedback) dari serangkaian hubungan sosial yang terjadi. Tulisan ini menegaskan posisi penulis dalam mengkaj $i$ masalah penelitian tidak hanya menempatkan objek pada perspektif positivisme, namun juga memberikan apresiasi pada perspektif kritis yang mendorong transformasi sosial dalam masyarakat desa agrowisata menuju tata kelola masyarakat yang lebih mandiri dan berkeadilan.

Sekalipun nilai (value) hubungan sosial mayarakat desa di keempat kawasan agrowisata secara perlahan mengalami perubahan dari penggunaan alur pengambilan keputusan logika yang mementingkan hubungan sosial non profit menuju kalkulatif-kontraktual yang berorientasi keuntungan (profit oriented,) namun senantiasa ada ragam upaya dilakukan warga desa untuk menjaga keluwesan hubungan sosial baik ekstrinsik maupun intrinsik. Satu hal yang penting dicermati bahwa dalam bentuk apapun respon masyarakat lokal maka hubungan sosial pada berbagai kegiatan produktif kreatif dalam pengelolaan agrowisata tetap merupakan salah satu faktor penentu proses diseminasi model pemberdayaan yang adaptif dalam mengutamakan keseimbangan motif sosial, ekonomi dan lingkungan.

\section{Simpulan dan Saran}

Pola hubungan sosial yang bermanfaat bagi realisasi pemberdayaan masyarakat desa melalui pengelolaan kawasan agrowisata dapat bersifat ekstrinsik dan intrinsik. Pada kedua pola hubungan sosial tersebut melekat motif kepentingan ekonomi sosial dalam kadar tak serupa. J alinan hubungan sosial asosiatif mempunyai potensi mendukung pemberdayaan masyarakat desa. Meski demikian, berbagai permasalahan ternyata rawan merintangi hubungan sosial komunikatif pada diseminasi model pemberdayaan masyarakat desa di kawasan agrowisata.

Hubungan sosial yang berorientasi kesadaran kolektif dibutuhkan dalam proses diseminasi model pemberdayaan masyarakat desa di kawasan agrowisata. Implementasi diseminasi model menunjukkan kemampuan awal untuk pembaharuan perilaku khalayak sasaran yang diberdayakan. Dari diseminasi model diperoleh beragam umpan balik yang diberikan warga desa terhadap kelayakan fungsi model. Hubungan sosial merupakan salah satu penentu proses diseminasi model.

\section{Daftar Pustaka}

Chamber, R. (1987). Pembangunan Desa Mulai dari Belakang. Penerbit LP3ES. Jakarta. 
IMAM S, DKK. Diseminasi Model Pemberdayaan Masyarakat Desa Melalui Pengelolaan Agrowisata

Miles, J., and Huberman. (1991). Designing Qualitative Research. McGraw Hill Company. New York.

Muldjono, P. (2010). Model Pemberdayaan Masyarakat melalui Posdaya (Pos Pemberdayaan Keluarga): The Model of Family Empowerment Program for Community Empowerment. Jumal Masyarakat, Kebudayaan dan Politik. Volume 23, Nomor 1, Tahun 2010. Universitas Airlangga. Surabaya.

Santoso, I. (1994). Pemberdayaan Petani Tepian Hutan melalui Pembaharuan Perilaku Adaptif. Disertasi pada Sekolah Pascasarjana Institut Pertanian Bogor. Bogor.

Santoso, I. dan Sulyana, D. (2005). Pengelolaan Sumberdaya Lingkungan Berbasis Kearifan Lokal. Penelitian (Belum Diterbitkan), Fakultas IImu Sosial dan IImu Politik Unsoed. Purwokerto.

Santoso, I. (2006). Pengembangan Model Alternatif Penanganan Kerawanan Pangan Rumahtangga Petani Miskin di Pedesaan Tepian Hutan. J urnal I Imiah Pekerjaan Sosial, Sekolah Tinggi Kesejahteraan Sosial. (STKS) Departemen Sosial Volume 5, No 1, J uni 2006. Jurnal Nasional Terakreditasi sesuai SK Dikti Nomor 39/ DIKTI/Kep 2004. Bandung.

Santoso, I., Priyono, R.E dan Santoso, J. (2007). Farmer Group Empowering Through Increasing Market Accessibility and Local Wisdom Utility. Collaborative Research Between Tokyo University-J apan and General Soedirman Uni-
versity-I ndonesia.

Stewart. J., (1994). Empowering People. Pustman Publishing. London.

Triharso, A. (2010). Pemikiran tentang Pemberdayaan Masyarakat Desa dan Peranan Pendidikan Tinggi: Implementasi dari Pro Konglomerasi Ke Pro UKM. Jurnal Masyarakat, Kebudayaan dan Politik. Volume 22, Nomor 4, Tahun 2010. Universitas Airlangga. Surabaya.

Usman, S. (2006). Pemberdayaan Masyarakat. Penerbit Pustaka Pelajar. Yogyakarta.

Wijaya, M. (2010). Ekonomi Komersial Ganda. Lembaga Pengembangan Pendidikan dan UPT Penerbitan dan Pencetakan UNS (UNS Press. Universitas Sebelas Maret Surakarta. Surakarta.

Wijaya, M. (2010). Kemiskinan dan Pemberdayaan Masyarakat Desa. Jumal of Rural and Development. Volume I Nomor 1, Pebruari 2010. Universitas Sebelas Maret Surakarta. Surakarta.

Wright, S. E., (2006). The Socio Cultural Impact of Ecotourism on the Indigeneous Peoples of the Wakatobi Marine National Park. Down Loaded from http://www.opwal.com/Indonesia.

Wrihatnolo, R.R., dan Dwidjowijoto, R.N. (2007). Manajemen Pemberdayaan. Sebuah Pengantar dan Panduan untuk Pemberdayaan Masyarakat. Elex Media Komputindo. Jakarta. 